\title{
The Effect of Recycled Glass Powder and Reject Fly Ash on the Mechanical Properties of Fibre-Reinforced Ultrahigh Performance Concrete
}

\author{
Shi Cong Kou ${ }^{1,2}$ and Feng Xing ${ }^{2}$ \\ ${ }^{1}$ Department of Civil and Structure Engineering, The Hong Kong Polytechnic University, Hong Kong \\ ${ }^{2}$ Guangdong Durability Center for Civil Engineering, College of Civil Engineering, ShenZhen University, Guangdong, China
}

Correspondence should be addressed to Shi Cong Kou, cesckou@polyu.edu.hk

Received 24 December 2011; Accepted 8 February 2012

Academic Editor: Nai-Qian Feng

Copyright (C) 2012 S. C. Kou and F. Xing. This is an open access article distributed under the Creative Commons Attribution License, which permits unrestricted use, distribution, and reproduction in any medium, provided the original work is properly cited.

\begin{abstract}
This paper presents an experimental study for the purpose of reducing the cost of producing ultrahigh performance fibrereinforced concrete (UHPFRC). Reject fly ash (r-FA) and recycled glass powder (GP) were examined as replacement materials for the silica sand and cement used to prepare UHPFRC, respectively. In addition, curing UHPFRC specimens at $25^{\circ} \mathrm{C}$ and $90^{\circ} \mathrm{C}$ was investigated to determine differences in mechanical properties. The results showed that using r-FA and GP reduces the flowability of fresh UHPFRC. The use of GP increased the mechanical properties of the UHPFRC. Moreover, the test results indicate a significant improvement in the mechanical properties of plain concrete by the inclusion of $r$-FA as partial replacement of fine aggregate (sand) and can be effectively used in UHPFRC. Furthermore, specimens cured at $25^{\circ} \mathrm{C}$ give lower compressive strength, flexural strength, and fracture energy than specimens cured at $90^{\circ} \mathrm{C}$.
\end{abstract}

\section{Introduction}

Ultrahigh performance fibre-reinforced concrete (UHPFRC) is a very special material with superior mechanical properties and low permeability [1-4], and when it is reinforced with steel fibres or steel tubes, it exhibits high ductility [5]. In recent years, UHPFRC has been successfully applied to dam repair, bridge deck overlays, coupling beams in high-rise buildings, and other specialized structures $[6,7]$.

However the high cost of UHPFRC is the disadvantage that restricts its wider usage. To alleviate both the environmental and economical impact of UHPFRC, industrial byproducts such as ground granulated blast-furnace slag (GGBS) and silica fume (SF), have been used as partial cement replacements without significantly affecting the mechanical properties $[5,8]$.

The recycling of waste glass is a major issue in urban areas of developed countries $[9,10]$, which has resulted in significant interest of late in utilizing it in concrete. Crushed glass has been used as a coarse aggregate in concrete
[11-14]. Attempts were made to use waste glass as a raw siliceous material in the production of Portland cement $[15,16]$. The use of coarse glass powder as a hydration enhancing filler has been explored [17, 18]. However, valued addition of glass in concrete is best achieved if it is used as a cement replacement material. Glass is amorphous and has high silica content, which are the primary requirements for a pozzolanic material. A particle size of $75 \mu \mathrm{m}$ or less is reported to be favourable for pozzolanic reaction [19]. The high alkali content of glass is a typical concern for its use in concrete, but studies $[9,10]$ have shown that finely ground glass does not contribute to alkali-silica reaction.

The properties which influence the pozzolanic behaviour of waste glass, and most pozzolans in general, are fineness, composition, and the pore solution present for reaction [20-24]. Based on observed compressive strengths, Meyer et al. [22] postulated that below $45 \mu \mathrm{m}$ glass may become pozzolanic. The pozzolanic properties of glass are first notable at particle sizes below approximately $300 \mu \mathrm{m}$. Below $100 \mu \mathrm{m}$, glass can have a pozzolanic reactivity which is greater 
than that of fly ash at low percent cement replacement levels and after 90 days of curing [23, 24].

The pozzolanic reactivity of fine waste glass is observed as an increase in compressive strength. In the reported data [23, 25], compressive strength is highest for specimens containing very fine glass $(<100 \mu \mathrm{m})$, and the strength decreases as particle size increases. A number of studies [25-31] showed the effect of percentages of waste glass replacing OPC and fine aggregate on the compressive strength of mortar bars. The results show that a cement replacement between 10\% and $20 \%$ yields the highest strength, while fine aggregate replacement of up to $40 \%$ has little effect on compressive strength.

About one million tonnes of fly ash, as a byproduct of electricity generation, is produced annually in Hong Kong. The finer fraction (f-FA) produced by passing the raw ash through a classifying process is routinely used in the production of blended cements for construction. This ash conforms to BS3892 [32], which has a fineness requirement of not more than $12 \%$ by mass retained on the $45-\mu \mathrm{m}$ test sieve and a maximum loss-on-ignition limit of $7 \%$. However, the remaining proportion, in the order of 200,000 tonnes, is rejected as a construction material, simply due to its large particle size. In Hong Kong, this rejected fly ash (r-FA) has to be disposed of in large lagoons, creating an everincreasing environmental hazard. Similar disposal problems can be expected in other coal-fired power stations.

The pozzolanic properties of r-FA in cement pastes have already been reported earlier, with encouraging results [33]. Poon and Ho suggested that it is technically feasible to utilize r-FA as part of the powder content in the production of SCC [34].

The use of low alkali cement and sand replacements in UHPFRC provides the opportunity to use finely recycled glass powder and r-FA as an economic replacement for cement and silica sand, respectively, this not only eliminates the risk of an expansive and deleterious alkali-silica reaction (ASR), but also the cost of the concrete can be reduced. This paper presents an experimental study for the purpose of reducing the cost of producing ultra-high performance fibre-reinforced concrete (UHPFRC). Reject fly ash (rFA) and recycled glass powder (GP) were examined as replacement materials for the silica sand and cement used to prepare UHPFRC, respectively. In addition, curing UHPFRC specimens at $25^{\circ} \mathrm{C}$ and $90^{\circ} \mathrm{C}$ was investigated to determine differences in mechanical properties.

\section{Experimental Details}

\subsection{Materials}

2.1.1. Cementitious Materials. Portland cement (CEM 1) and two different types of supplementary cementitious materials were used in this study, that is, recycled waste glass powder (GP) and silica fume (SF). The investigated glass powder samples were derived from recycled glass bottles and dry comminuted in a laboratory shaking mill to obtain particles smaller than $0.045 \mathrm{~mm}$. A condensed silica fume (SF) named Force 10,000 D microsilica with density of $2.22 \mathrm{~g} / \mathrm{cm}^{3}$
TABLe 1: Chemical composition of cement, recycled glass powder, and silica fume.

\begin{tabular}{lccc}
\hline Contents & Cement & Silica fume & $\begin{array}{c}\text { Recycled } \\
\text { glass powder }\end{array}$ \\
\hline $\mathrm{SiO}_{2}$ & 21.0 & $85-96$ & 71.4 \\
$\mathrm{Al}_{2} \mathrm{O}_{3}$ & 5.9 & - & 1.4 \\
$\mathrm{Fe}_{2} \mathrm{O}_{3}$ & 3.4 & - & 0.2 \\
$\mathrm{CaO}$ & 64.7 & - & 10.6 \\
$\mathrm{MgO}$ & 0.9 & - & 2.5 \\
$\mathrm{Na}_{2} \mathrm{O}$ & - & - & 12.7 \\
$\mathrm{~K}_{2} \mathrm{O}$ & - & - & 0.5 \\
$\mathrm{TiO}_{2}$ & - & - & - \\
$\mathrm{SO}_{3}$ & 2.6 & $0.3-0.7$ & 0.1 \\
Loss on ignition (\%) & 1.2 & 3.5 & 0.4 \\
\hline
\end{tabular}

Table 2: Properties of Portland cement (OPC), recycled glass powder (GP), and rejected fly ash (r-FA).

\begin{tabular}{lccc}
\hline & OPC & GP & r-FA \\
\hline Specific gravity & 3.16 & 2.48 & 2.19 \\
Blaine fineness $\left(\mathrm{m}^{2} / \mathrm{kg}\right)$ & 352 & 756 & 119 \\
Initial set $(\mathrm{min})$ & 150 & - & - \\
Final set (min) & 235 & - & - \\
Loss on ignition (\%) & 2.97 & 0.16 & 8.06 \\
Sieve & & Cumulative \% passing \\
$1.18 \mathrm{~mm}$ & - & - & 100 \\
$0.6 \mathrm{~mm}$ & - & - & 99.1 \\
$0.3 \mathrm{~mm}$ & - & - & 95.6 \\
$0.15 \mathrm{~mm}$ & 100 & - & 87.7 \\
$0.075 \mathrm{~mm}$ & 98.6 & - & 61.7 \\
$0.045 \mathrm{~mm}$ & 95.0 & 100 & 50.2 \\
\hline
\end{tabular}

obtained from W. Grace was used. The chemical, physical, and mechanical properties of cement, GP, and SF used in this study are shown in Tables 1 and 2 .

\subsubsection{Aggregate}

(a) Silica Sand. The Silica sand used in this study is a commercial product, provided by Hong Kong Winlong Minerals LTD., has a narrow grading distribution between 150 and $300 \mu \mathrm{m}$ for approximately $90 \%$ of particles.

(b) Reject Fly Ash ( $r-F A$ ). The r-FA with particle sizes larger than $45 \mu \mathrm{m}$ were used in this study and were generated as byproducts from a local coal-fired power plant. The particle size distribution of $\mathrm{r}-\mathrm{FA}$ is also shown in Table 2.

2.1.3. Steel Fibre. The special steel fibres were obtained from local company which are made using high carbon steel with a tensile strength of $2000 \mathrm{MPa}$ and conform to the British Standard [35]. Each fibre is coated with brass and is $0.2 \mathrm{~mm}$ in diameter and $13 \mathrm{~mm}$ in length. 
TABLE 3: Mix proportion of UHPFRC.

$$
\text { Proportion }\left(\mathrm{kg} / \mathrm{m}^{3}\right)
$$

\begin{tabular}{|c|c|c|c|c|c|c|c|c|}
\hline \multirow[t]{2}{*}{ Mix notation } & & \multicolumn{3}{|c|}{$\begin{array}{l}\text { Cementitious component } \\
\text { (level of cement replacement) }\end{array}$} & \multicolumn{2}{|c|}{$\begin{array}{c}\text { Aggregate } \\
\text { (level of sand replacement) }\end{array}$} & \multirow[t]{2}{*}{$\mathrm{W} / \mathrm{B}$} & \multirow[t]{2}{*}{$\begin{array}{c}\text { ADVA } 109 \text { (\% solid by } \\
\text { weight of binder) }\end{array}$} \\
\hline & & Cement & Silica fume & Glass powder & Silica sand & r-FA & & \\
\hline \multirow{3}{*}{ Series I } & Control & 1062 & $118(10 \%)$ & 0 & 1094 & 0 & 0.15 & 1.05 \\
\hline & GP-15 & 903 & $118(10 \%)$ & $159(15 \%)$ & 1058 & 0 & 0.15 & 1.05 \\
\hline & GP-30 & 743 & $118(10 \%)$ & $319(30 \%)$ & 1021 & 0 & 0.15 & 1.05 \\
\hline \multirow{3}{*}{ Series II } & r-FA-15 & 1062 & $118(10 \%)$ & - & 887 & $171(15 \%)$ & 0.15 & 1.05 \\
\hline & r-FA-30 & 1062 & $118(10 \%)$ & - & 697 & $328(30 \%)$ & 0.15 & 1.05 \\
\hline & r-FA-50 & 1062 & $118(10 \%)$ & 一 & 432 & $547(50 \%)$ & 0.15 & 1.05 \\
\hline \multirow{2}{*}{ Series III } & $\mathrm{G} 15+\mathrm{rFA} 15$ & 903 & $118(10 \%)$ & $159(15 \%)$ & 851 & $171(15 \%)$ & 0.15 & 1.05 \\
\hline & $\mathrm{G} 15+\mathrm{rFA} 30$ & 903 & $118(10 \%)$ & $159(10 \%)$ & 661 & $328(30 \%)$ & 0.15 & 1.05 \\
\hline
\end{tabular}

TABLE 4: Test schedule of mechanical properties of UHPFRC.

\begin{tabular}{lllcccc}
\hline & \multicolumn{5}{c}{ Curing age (days) } \\
& 1 & 4 & 7 & 28 & 90 & 365 \\
\hline $25^{\circ} \mathrm{C}$ curing & Comp/flex & Comp & Comp & Comp/flex & Comp/flex & Comp/flex \\
$90^{\circ} \mathrm{C}$ curing & Comp/flex & Comp & Comp & Comp/flex & Comp/flex & Comp/flex \\
\hline
\end{tabular}

2.1.4. Superplasticiser. The superplasticiser used in this study was ADVA 109 which is polycarboxylate based and commercially available in Hong Kong.

2.2. Mix Proportions. Three series of UHPFRC mixtures with different recycled glass powder and r-FA content were prepared. In all concrete mixtures, the silica fume content was kept constant at levels of $128 \mathrm{~kg} / \mathrm{m}^{3}$, and the steel fibre content of UHPFRC was $2 \%$ by volume of the total mixture. This is commonly considered the optimum proportion to achieve a balance between mechanical properties and financial cost [36]. Use of the superplasticiser (ADVA 109) enabled a water-binder ratio of 0.15 to be achieved, which met the low water requirement of UHPFRC $[2,5]$. In Series I, two UHPFRC mixtures were prepared with recycled glass powder (GP). The GP was used as 15 and $30 \%$ by weight replacement of the cement. In Series II, three concrete mixtures were prepared with r-FA which were used as 15 , 30 , and $50 \%$ by weight replacement of the silica sand. In Series III, two UHPFRC mixtures were prepared with cement replacement level of $15 \%$ by GP and sand replacement level of 15 and $30 \%$ by r-FA, respectively. The control mixture was prepared with only cement, silica fume, steel fibre, and silica sand to compare the mechanical properties of the concrete. The detailed mix proportions of the UHPFRC are shown in Table 3.

2.3. Specimen Preparation. Each series of specimens was cast comprising $50 \mathrm{~mm}$ cubes for compressive strength [37] and $40 \times 40 \times 160 \mathrm{~mm}$ prisms for flexural strength [38]. The solid UHPFRC mix constituents, in the order of cement, SF, $\mathrm{GP}$, and sand or r-FA, were weighed according to the mix proportions and dry mixed in a horizontal pan mixer with a 15-1 capability for approximately $1 \mathrm{~min}$. The mixture of water and superplasticiser was gradually added to the rotating mixer. The steel fibres were added after mixing for approximately $10 \mathrm{~min}$. This time enabled the superplasticiser to become fully effective and a consistent mixture was reached. Usually, a further mix duration of approximately $5 \mathrm{~min}$ helped to achieve good flowability and an even distribution of steel fibres in the cement matrix. The fresh UHPFRC was then transferred into steel moulds and compacted for 1 min using a vibrating table. The specimens were then covered with damp hessian and polythene sheeting. After one day, they were demoulded and cured in water either at $20^{\circ} \mathrm{C}$ or at $90^{\circ} \mathrm{C}$. The heat cured specimens were stored in a hot water bath from the age of 1 day. These specimens were then stored in air at room temperature until testing. The $20^{\circ} \mathrm{C}$ cured specimens were kept in a standard curing tank until testing.

2.4. Testing. The workability of the fresh concrete was measured with a flow table [39]. All cube specimens were tested using a loading rate of $0.8 \mathrm{kN} / \mathrm{s}$ [37]. The prism specimens were tested under four-point loading using displacement control and using a testing machine controlled by an external displacement transducer, such that the mid-span deflection rate of the prism specimen was held constant throughout the test. The specimen mid-span deflection rate was $0.15 \mathrm{~mm} / \mathrm{min}$, with a span of $120 \mathrm{~mm}$. The fracture energy [40] of specimens tested was calculated by integrating the area under the flexural stress versus deflection up to $1.25 \mathrm{~mm}$. The mechanical test schedule of UHPFRC specimens is shown in Table 4 and each reading was taken as the average of three test results. 


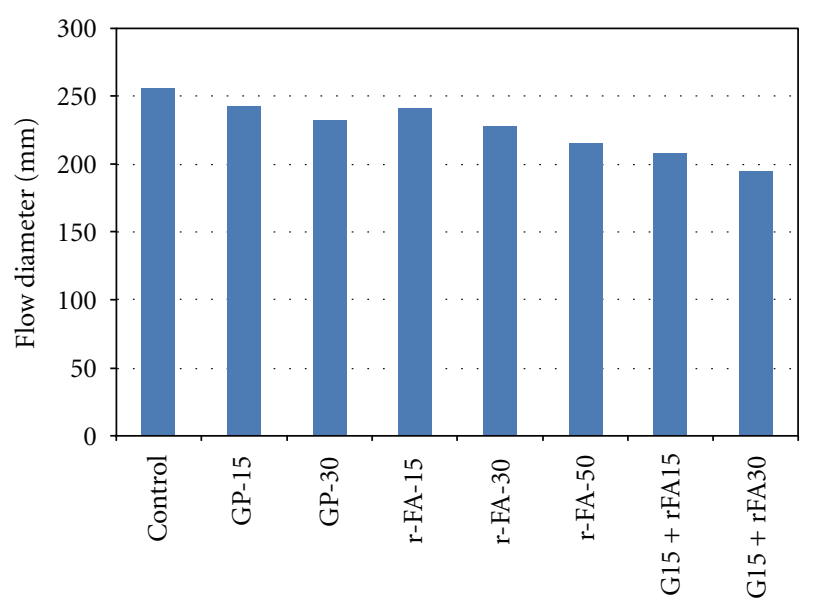

FIGURE 1: Flow diameter of concrete.

\section{Results and Discussion}

3.1. Fresh Concrete. Figure 1 shows measurements from the flow table test. It can be seen that the flow diameter of concrete varied between 256 and $195 \mathrm{~mm}$ in the sequence of Control, GP-15, GP-30, r-FA-15, r-FA-30, r-FA-50, G15+rFA30, and G15+rFA30. Moreover, the flow diameter of concrete decreased with an increase in recycled glass powder and r-FA content. Concrete mixture G15+rFA30 with 15\% of glass powder and 30\% of r-FA had the lowest slump flow value of $195 \mathrm{~mm}$. It was observed during mixing and testing that the flowability of the fresh concrete had a close relationship with the fineness of the cementitious materials and the aggregate. The same sequence of Control, GP-15, GP30, r-FA-15, r-FA-30, r-FA-50, G15+rFA30, and G15+rFA30 was followed as the fineness of the materials. No bleeding segregation was observed when mixing.

\subsection{Hardened Concrete}

3.2.1. Effect of GP, $r$-FA, and Steam Curing on the Compressive Strength of UHPFRC. The development of the compressive strength of UHPFRC prepared with GP, r-FA and GP+rFA is illustrated in Figures 2-4, respectively. Each presented value is the average of three measurements. It is seen from Figure 2 that at early ages (before 7 days), the use of GP as a partial replacement of cement caused a reduction in the compressive strength. At day 1, the UHPFRC mixtures GP-15 and GP-30 prepared with 15\% and 30\% GP had an average of $4.4 \%$ and $11.8 \%$ reduction in compressive strength compared to the control mixture. However, after 28 days, the replacement of cement with glass powder increased the compressive strength of the concrete mixtures, while the rate of increase in strength decreased with increase in GP content. The concrete mixtures prepared with $15 \%$ GP had an average $7.0 \%$ increase in compressive strength compared to the control mixture, whereas the corresponding concrete mixture with $30 \%$ GP had only a $2.82 \%$ increase in strength. This is consistent with the results of Shi et al. [20]

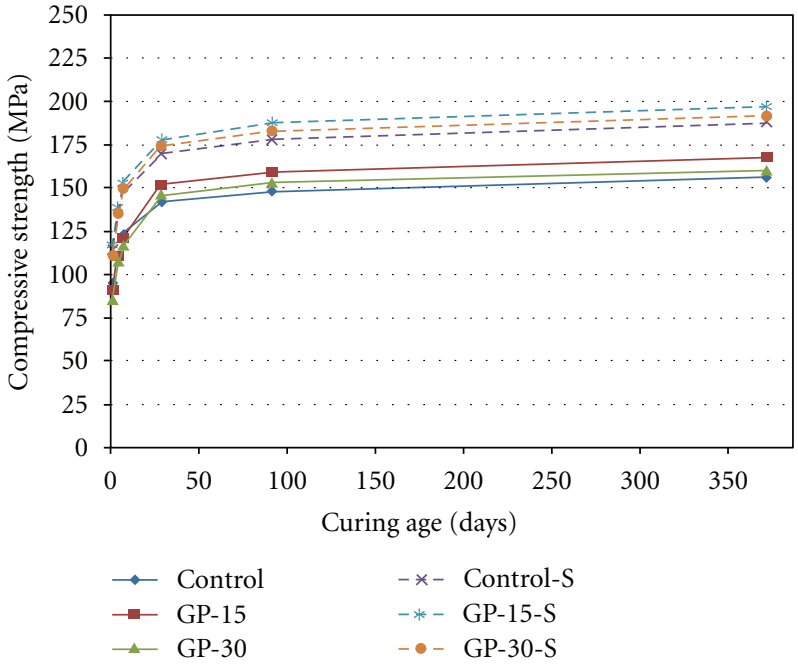

FIGURE 2: Effect of GP on compressive strength of UHPFRC with and without steam curing.

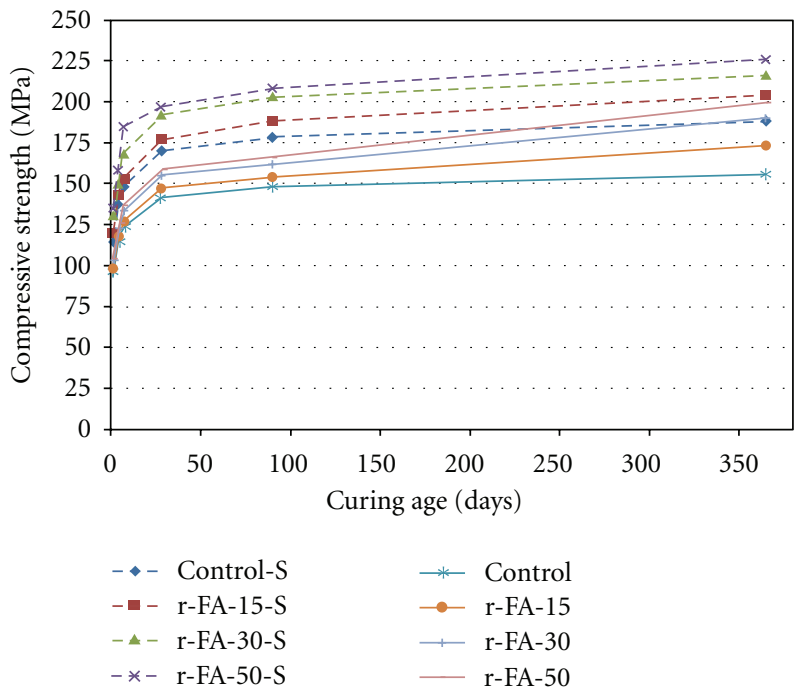

FIGURE 3: Effect of r-FA on compressive strength of UHPFRC with and without steam curing.

who indicated that glass powders with particle smaller than $60 \mu \mathrm{m}$ have very high pozzolanic reactivity; a replacement of $20 \%$ cement with ground glass powder can develop higher strength than $100 \%$ Portland cement at 28 days.

Figure 2 also indicates that after steam cured at $90^{\circ} \mathrm{C}$, the compressive strengths of the concrete mixtures control, GP-15, and GP-30 were 20.5\%, 28.6\% and 30.6\% higher than the corresponding concrete with standard curing at $25^{\circ} \mathrm{C}$. Moreover, at all test ages, the steam cured UHPFRC at $90^{\circ} \mathrm{C}$ had higher compressive strength than corresponding concrete with standard curing at $25^{\circ} \mathrm{C}$.

After 365 days the $25^{\circ} \mathrm{C}$ cured specimens had a very high compressive strength but did not match that of the $90^{\circ} \mathrm{C}$ cured specimens. From observations of the rate of increase in strength it seems unlikely that the strength of the $25^{\circ} \mathrm{C}$ cured 


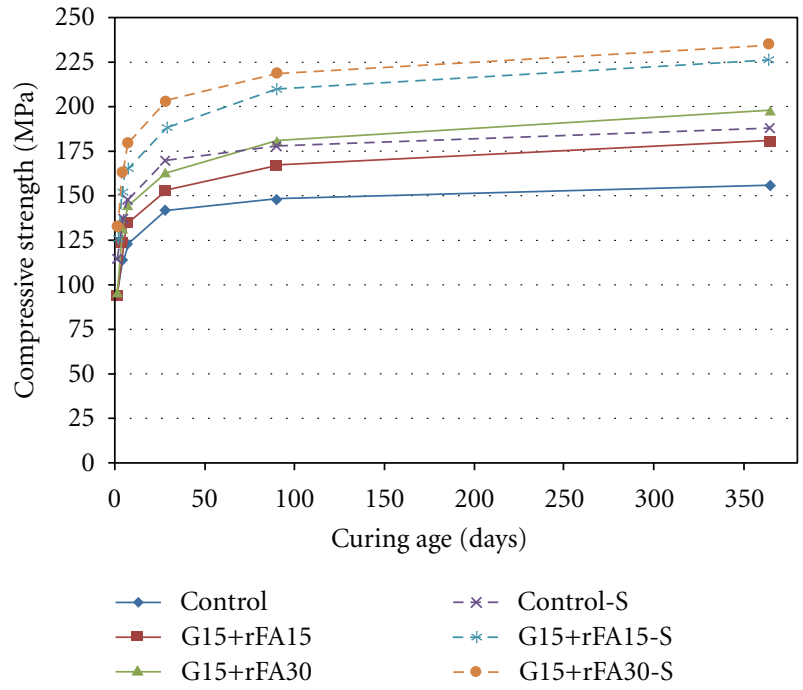

FIGURE 4: Effect of both GP and r-FA on compressive strength of UHPFRC with and without steam curing.

specimens would reach that of the $90^{\circ} \mathrm{C}$ cured specimens at later ages. However, the compressive strengths of $25^{\circ} \mathrm{C}$ cured UHPFRC at 28 days, that is, $140-150 \mathrm{MPa}$, are still considered very high strength and this can be applied very effectively for building structures.

Figure 3 shows the variation in compressive strength of UHPFRC with r-FA percentages at different ages. From the test results, it can be seen that the compressive strength of UHPFRC mixtures with $15 \%, 30 \%$, and $50 \%$ silica sand replacement with r-FA, were higher than the control mixture at all ages. Moreover, there is increase in strength with increase in r-FA percentages; however, the rate of increase of strength decreases with the increase in r-FA content. This trend is more obvious between $30 \%$ and $50 \%$ replacement levels. Maximum strength at all ages occurs with $50 \%$ fine aggregate replacement. At 1 day, the compressive strength of the concrete mixtures r-FA-15, r-FA-30, and r-FA-50 with $15 \%, 30 \%$, and $50 \%$ r-FA was about $3 \%, 8 \%$, and $10 \%$ higher than the control mixture, whereas at 365 days, the corresponding concrete mixture had an average $10.9 \%, 21.8 \%$, and $27.6 \%$ increase in compressive strength compared to the control mixture. This increase in strength due to the replacement of fine aggregate with $\mathrm{r}-\mathrm{FA}$ is attributed to (1) the improvement of packing density with r-FA and (2) the pozzolanic action of $r-F A$. In the beginning (early age), r-FA reacts very slowly with calcium hydroxide liberated during hydration of cement and does not contribute significantly to the densification of the concrete matrix at early ages. Concrete with r-FA shows higher strength at early ages because inclusion of r-FA as partial replacement of sand starts pozzolanic action and densification of the concrete matrix, and due to this strength of r-FA concrete is higher than the strength of the control mixture even at early ages.

It is clear from Figure 3 that the steam curing at $90^{\circ} \mathrm{C}$ increased the compressive strength of r-FA UHPFRC at all test ages. The rate of increase in strength at an early age

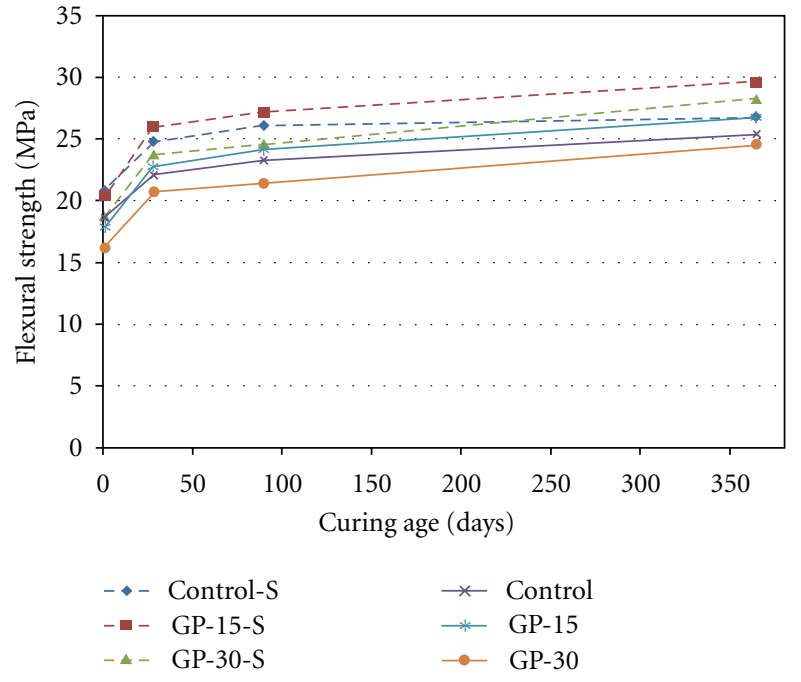

FIGURE 5: Effect of GP on flexural strength of UHPFRC with and without steam curing.

(before 28 days) was higher than that at a late stage (365 days). At 1 day, for the concrete mixtures with $15 \%, 30 \%$, and $50 \% \mathrm{r}-\mathrm{FA}$, the steam curing increased the compressive strength by $22.4 \%, 26.2 \%$, and $28.6 \%$ respectively, when compared with the corresponding concrete mixtures with standard curing at $25^{\circ} \mathrm{C}$, whereas, at 365 days, these increased values were reduced to $17.9 \%, 13.7 \%$, and $13.6 \%$, respectively.

Figure 4 shows the effect of combined GP and r-FA on the compressive strength of UHPFRC. It is seen that at 1 day, the compressive strength of concrete mixtures G15+rFA15 and $\mathrm{G} 15+\mathrm{rFA} 30$ with standard curing at $25^{\circ} \mathrm{C}$ was similar to that of the control mixture. However, at 365 days, the compressive strength of the corresponding concrete mixtures was $16.0 \%$ and $26.9 \%$ higher than that of the control mixture, respectively. The concrete mixture G15+rFA30 had the highest compressive strength. This might be attributed to the pozzolanic reaction between both GP and r-FA and $\mathrm{Ca}(\mathrm{OH})_{2}$. Figure 4 also indicates that at all test ages, the steam curing at $90^{\circ} \mathrm{C}$ significantly increased the compressive strength of the concrete prepared with both GP and rFA. After 1 day steam curing at $90^{\circ} \mathrm{C}$, the compressive strength of concrete mixtures G15+rFA15 and G15+rFA30 was $33.1 \%$ and $38.5 \%$ higher than corresponding concrete with standard curing at $25^{\circ} \mathrm{C}$.

3.2.2. Effect of GP, $r$-FA and Steam Curing on the Flexural Strength of UHPFRC. Figures 5-7 show the development of the flexural strength of UHPFRC made with GP, r-FA, and $\mathrm{GP}+\mathrm{rFA}$, respectively. Each presented value is the average of three measurements. From Figure 5, it can be seen that at 1 day, the replacement of cement with GP reduced the flexural strength of the concrete. The concrete mixture GP-30 had the lowest flexural strength, whereas after 28 days, the replacement of cement by $15 \%$ GP increased the flexural strength of the concrete. Moreover, the flexural strength of concrete mixtures GP-15 and GP-30 was increased with steam curing 


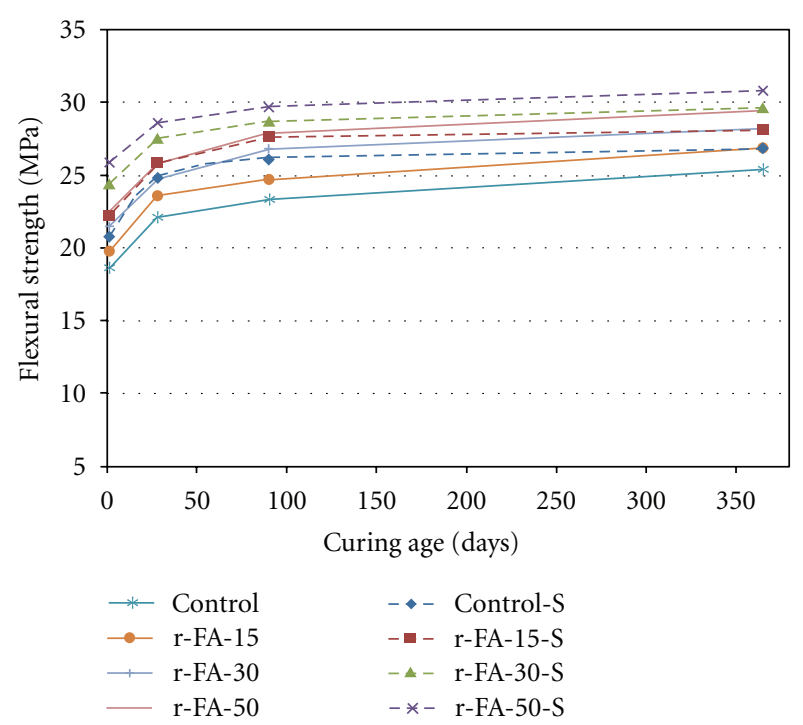

Figure 6: Effect of r-FA on flexural strength of UHPFRC with and without steam curing.

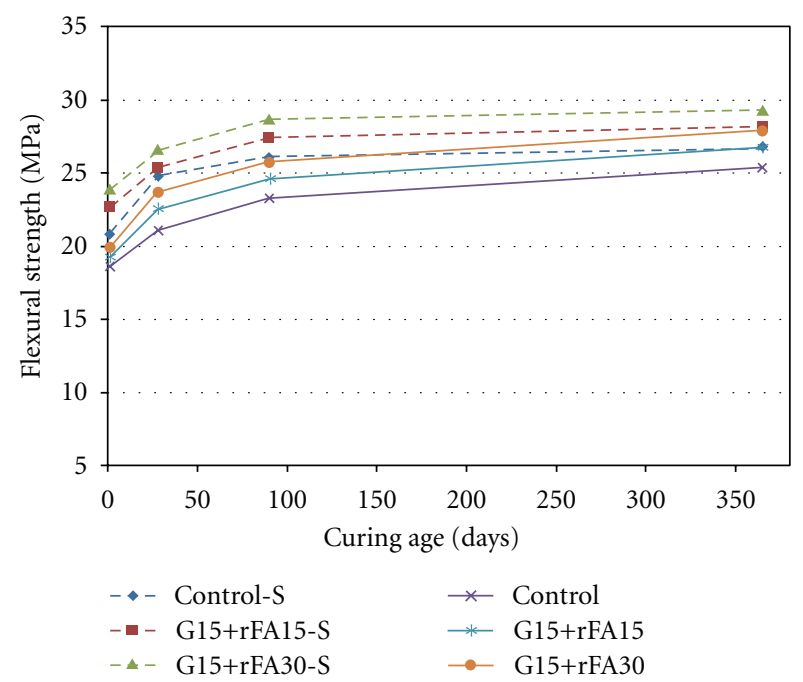

Figure 7: Effect of both GP and r-FA on flexural strength of UHPFRC with and without steam curing.

at $90^{\circ} \mathrm{C}$. After 1-day steam curing, the flexural strength of concrete mixtures GP-15 and GP-30 was $14.6 \%$ and $16.0 \%$ higher than corresponding concrete with standard curing. Furthermore, the rate of increase in strength of the concrete mixtures with GP was higher than that of control mixture.

It is clear from Figure 6 that the replacement of silica sand by r-FA increased the flexural strength of the concrete mixture with both standard curing at $25^{\circ} \mathrm{C}$ and steam curing at $90^{\circ} \mathrm{C}$ at all ages. At 28 days, the flexural strength of standard cured concrete mixtures r-FA-15, r-FA-30 and r-FA50 was $6.8 \%, 11.8 \%$, and $16.7 \%$ higher, respectively than that of control mixture. Moreover, flexural strength continued to increase with increase in r-FA percentages at all ages, and there was significant increase in strength compared to that of the control mixture. This is believed to be due to the

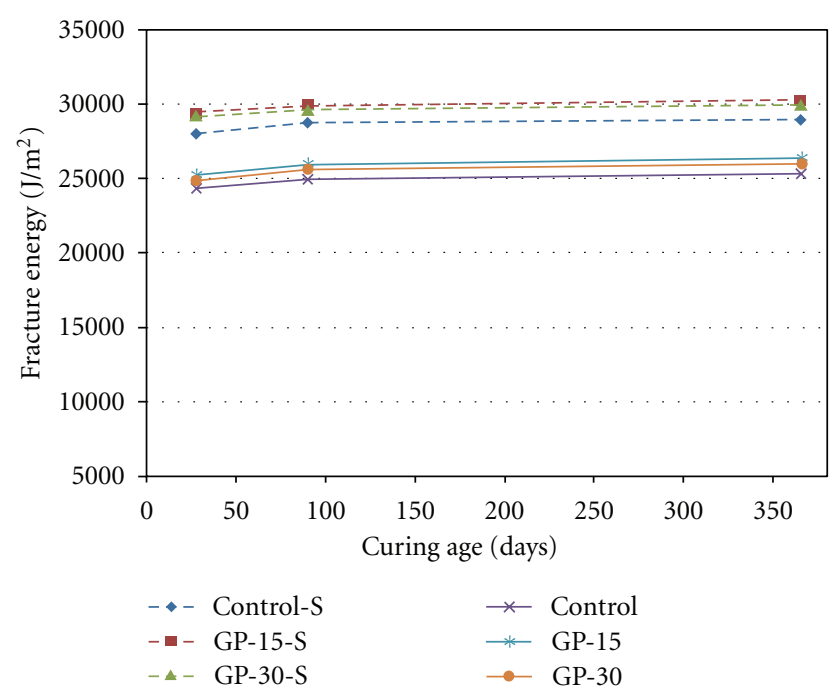

FIGURE 8: Effect of GP on fracture energy of UHPFRC with and without steam curing.

large pozzolanic reaction and improved interfacial bonding between the paste and aggregates. After 1-day steam curing, the flexural strength of concrete mixtures r-FA-15, r-FA30 , and r-FA-50 was $12.1 \%, 14.0 \%$, and $15.1 \%$ higher than corresponding concrete with standard curing.

Figure 7 shows the effect of combined GP and r-FA on the flexural strength of UHPFRC. It is seen that both the replacement of cement and sand by GP and r-FA, respectively, increased the flexural strength of the concrete. At 1 day, the flexural strength of concrete mixtures G15+rFA15 and G15+rFA30 with standard curing at $25^{\circ} \mathrm{C}$ was increased by $3.2 \%$ and $7.0 \%$, respectively, when compared with the control mixture. However, at 365 days, the flexural strength of the corresponding concrete mixtures was $5.5 \%$ and $9.8 \%$ higher than that of the control mixture, respectively. The concrete mixture G15+rFA30 had the highest flexural strength. Figure 7 also indicates that at all ages, the steam curing at $90^{\circ} \mathrm{C}$ significantly increased the flexural strength of the concrete prepared with both GP and r-FA.

\subsubsection{Effect of GP, r-FA and Steam Curing on the Fraction} Energy of UHPFRC. The fracture energy versus age of UHPFRC specimens prepared with GP, r-FA and steam curing are shown in Figures 8-10. Each presented value is the average of three measurements. It is seen from Figure 8 that at all ages, the replacement of cement by GP increased the fracture energy of the concrete with both standard curing at $25^{\circ} \mathrm{C}$ and steam curing at $90^{\circ} \mathrm{C}$. At 28 days, the replacement of cement by $15 \%$ and $30 \%$ GP increased the fracture energy by $3.6 \%$ and $2.2 \%$, respectively. This may be attributed to the pozzolanic reaction between $\mathrm{GP}$ and $\mathrm{Ca}(\mathrm{OH})_{2}$ in the concrete which further increases the bond strength between fibre and matrix. Moreover, at 28 days, comparison of the properties from UHPFRC mixtures control, GP-15 and GP30 cured at $90^{\circ} \mathrm{C}$ and $20^{\circ} \mathrm{C}$ shows that $20^{\circ} \mathrm{C}$ cured UHPFRC 


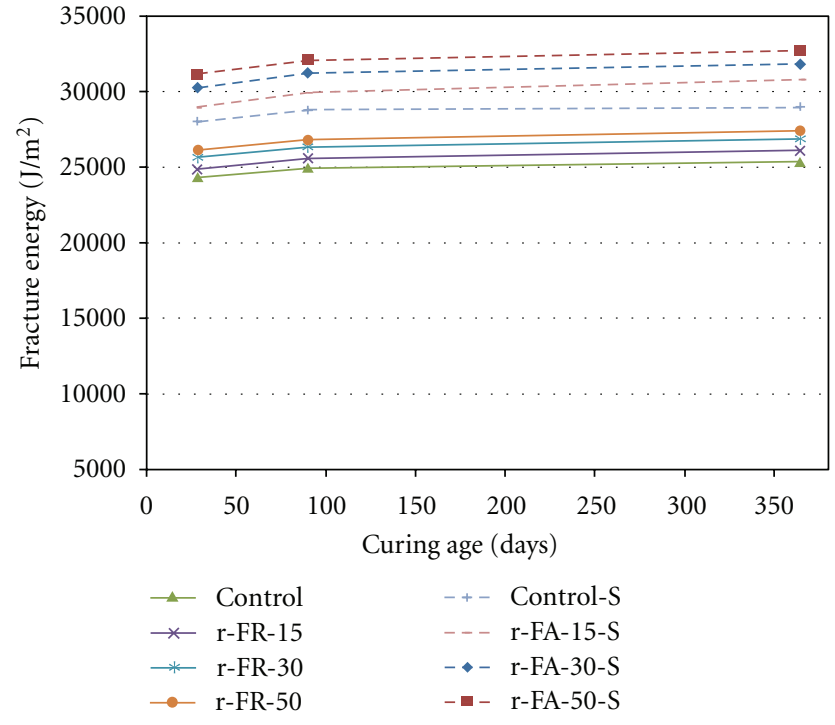

FIGURE 9: Effect of r-FA on fracture energy of UHPFRC with and without steam curing.

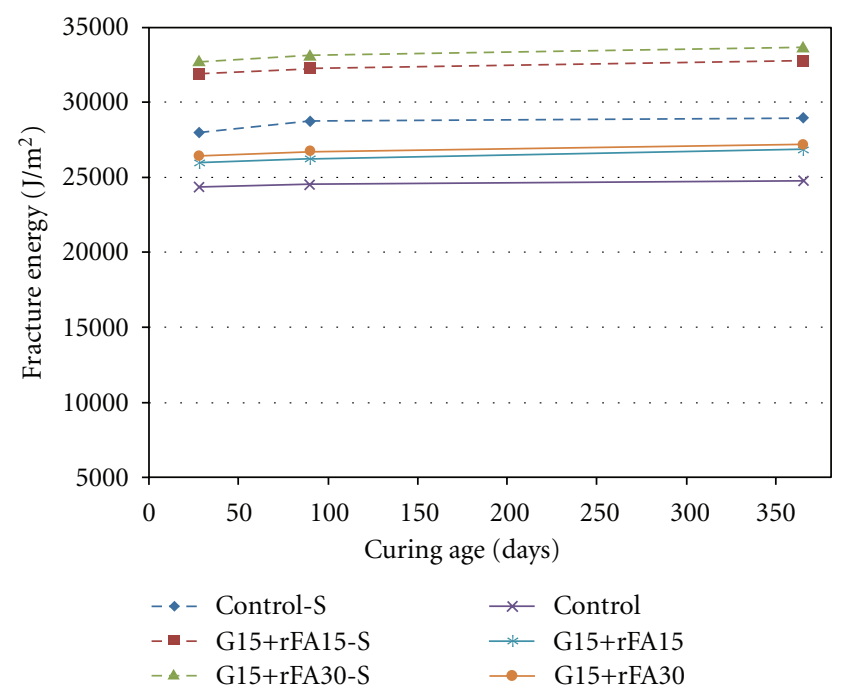

Figure 10: Effect of both GP and r-FA on fracture energy of UHPFRC with and without steam curing.

is $15 \%, 16.6 \%$, and $17.2 \%$ lower, respectively, in compressive strength.

Figure 9 indicates that at all ages, the replacement of sand by r-FA increased the fracture energy of the concrete with both standard curing at $25^{\circ} \mathrm{C}$ and steam curing at $90^{\circ} \mathrm{C}$. Moreover, the fracture energy was increased with increase in r-FA content. As the fracture energy is closely related to efficiency of the fibre bond, the variation in fracture energy can be attributed to a different bond action for fibres embedded in the concrete matrix. For r-FA specimens, the fibres appeared to keep their original direction in the concrete matrix before being pulled out. The greater fineness of r-FA aggregate can also facilitate the propagation of cracks, initially due to a stronger bond between the r-FA particles and the cement paste. Subsequently the r-FA aggregate can initiate matrix strengthening which further increases the fibre bonding strength.

Figure 10 shows the effect of combined GP and r-FA on the fracture energy of UHPFRC. It can be obtained that at all ages, the replacement of cement and sand by GP and rFA, respectively, increased the fracture energy of the concrete with both standard curing at $25^{\circ} \mathrm{C}$ and steam curing at $90^{\circ} \mathrm{C}$. At 28 days, the fracture energy of concrete mixture G15+rFA15 and G15+rFA30 with steam curing at $90^{\circ} \mathrm{C}$ was $22.5 \%$ and $24 \%$ higher than that corresponding concrete with standard curing at $25^{\circ} \mathrm{C}$, respectively. Moreover, the fracture energy of the concrete was increased with increase in r-FA content. The concrete mixture G15+rFA30 had the highest fracture energy.

\section{Conclusion}

The following conclusions can be drawn from the present investigation.

(1) The replacement of cement by glass powder decreased the early (before 7 days), but increased the later (after 28 days) compressive strength, flexural strength, and fracture energy of UHPFRC.

(2) Compressive strength, flexural strength, and fracture energy of silica-sand-replaced r-FA UHPFRC specimens were higher than for the control specimens at all ages.

(3) At all ages, the replacement of cement and sand by GP and r-FA, respectively, increased the compressive strength, flexural strength, and fracture energy.

(4) Steam curing at $90^{\circ} \mathrm{C}$ increased the compressive strength between $20 \%$ and $30 \%$ for GP concrete, $20 \%$ and $28 \%$ for r-FA concrete, and $20 \%$ and $38 \%$ for $\mathrm{GP}+\mathrm{rFA}$ concrete; the flexural strength between $11 \%$ and $16 \%$ for GP concrete, $11 \%$ and $15 \%$ for r-FA concrete, and $11 \%$ and $20 \%$ for GP+rFA concrete; and fracture energy between $15 \%$ and $17 \%$ for GP concrete, $15 \%$ and $19 \%$ for r-FA concrete, and 15\% and $24 \%$ for GP+rFA concrete.

(5) Glass powder and r-FA can be used to replace cement and sand for producing lower cost UHPFRC.

\section{References}

[1] H. H. Bache, "Introduction to compact reinforced composite," Nordic Concrete Research, no. 6, pp. 19-33, 1987.

[2] P. Richard and M. Cheyrezy, "Composition of reactive powder concretes," Cement and Concrete Research, vol. 25, no. 7, pp. 1501-1511, 1995.

[3] P. Rossi, A. Arca, E. Parant, and P. Fakhri, "Bending and compressive behaviours of a new cement composite," Cement and Concrete Research, vol. 35, no. 1, pp. 27-33, 2005.

[4] J. P. Charron, E. Denarié, and E. Brühwiler, "Permeability of UHPFRC under high stresses," in Proceedings of the RILEM Symposium on Advances in Concrete Through Science and Engineering, p. 12, Evanston, Ill, USA, March 2004. 
[5] T. T. Le, M. N. Soutsos, S. G. Millard, and S. J. Barnett, "Ultra high performance fiberreinforced concrete-optimisation of mix proportions," in Proceedings of the International Conference Entitled Concrete Platform, pp. 339-349, Belfast, UK, 2007.

[6] M. Schmidt and E. Fehling, "Ultra-high-performance concrete research development and application in Europe," in Proceedings of the 7th international Symposium on the Utilization of High-Strength/High-Performance Concrete, American Concrete Institute, Washington, DC, USA, 2005.

[7] V. C. Li, "Strategies for high performance fiber reinforced cementitious composites development. Fiber reinforced concrete: from theory to practice," in Proceedings of the North American/European Workshop on Advances in Fiber Reinforced Concrete, pp. 93-98, Bergamo, Italy, 2004.

[8] A. Oner and S. Akyuz, "An experimental study on optimum usage of GGBS for the compressive strength of concrete," Cement and Concrete Composites, vol. 29, no. 6, pp. 505-514, 2007.

[9] W. Jin, C. Meyer, and S. Baxter, "Glascrete-Concrete with glass aggregate," ACI Structural Journal, vol. 97, no. 2, pp. 208213,2000 .

[10] A. Shayan and A. Xu, "Value-added utilisation of waste glass in concrete," Cement and Concrete Research, vol. 34, no. 1, pp. 81-89, 2004.

[11] C. Meyer, N. Egosi, and C. Andela, "Concrete with waste glass as aggregate," in Recycling and Reuse of Glass Cullet. Proceedings of the International Symposium, Concrete technology unit of ASCE and University of Dundee, March 2001.

[12] I. B. Topçu and M. Canbaz, "Properties of concrete containing waste glass," Cement and Concrete Research, vol. 34, no. 2, pp. 267-274, 2004.

[13] C. M. Sangha, A. M. Alani, and P. J. Walden, "Relative strength of green glass cullet concrete," Magazine of Concrete Research, vol. 56, no. 5, pp. 293-297, 2004.

[14] S. B. Park, B. C. Lee, and J. H. Kim, "Studies on mechanical properties of concrete containing waste glass aggregate," Cement and Concrete Research, vol. 34, no. 12, pp. 2181-2189, 2004.

[15] G. Chen, H. Lee, K. L. Young et al., "Glass recycling in cement production-an innovative approach," Waste Management, vol. 22, no. 7, pp. 747-753, 2002.

[16] Z. Xie and Y. Xi, "Use of recycled glass as a raw material in the manufacture of Portland cement," Materials and Structures/ Materiaux et Constructions, vol. 35, no. 252, pp. 510-515, 2002.

[17] N. Neithalath and N. Schwarz, "Cement pastes incorporating coarse glass powder hydration, strength, and heat development," Materials and Structures. In press.

[18] N. Schwarz, M. DuBois, and N. Neithalath, "Electrical conductivity based characterization of plain and coarse glass powder modified cement pastes," Cement and Concrete Composites, vol. 29, no. 9, pp. 656-666, 2007.

[19] Y. Shao, T. Lefort, S. Moras, and D. Rodriguez, "Studies on concrete containing ground waste glass," Cement and Concrete Research, vol. 30, no. 1, pp. 91-100, 2000.

[20] C. Shi, Y. Wu, C. Riefler, and H. Wang, "Characteristics and pozzolanic reactivity of glass powders," Cement and Concrete Research, vol. 35, no. 5, pp. 987-993, 2005.

[21] A. Shayan and A. Xu, "Performance of glass powder as a pozzolanic material in concrete: a field trial on concrete slabs," Cement and Concrete Research, vol. 36, no. 3, pp. 457-468, 2006.

[22] C. Meyer, S. Baxter, and W. Jin, "Potential of waste glass for concrete masonry blocks," in Proceedings of the 4th Materials
Engineering Conference, pp. 666-673, Washington, DC, USA, November 1996.

[23] C. Shi, Y. Wu, C. Riefler, and H. Wang, "Characteristics and pozzolanic reactivity of glass powders," Cement and Concrete Research, vol. 35, no. 5, pp. 987-993, 2005.

[24] N. Schwarz, H. Cam, and N. Neithalath, "Influence of a fine glass powder on the durability characteristics of concrete and its comparison to fly ash," Cement and Concrete Composites, vol. 30, no. 6, pp. 486-496, 2008.

[25] Y. Shao, T. Lefort, S. Moras, and D. Rodriguez, "Studies on concrete containing ground waste glass," Cement and Concrete Research, vol. 30, no. 1, pp. 91-100, 2000.

[26] A. Shayan and A. Xu, "Value-added utilisation of waste glass in concrete," Cement and Concrete Research, vol. 34, no. 1, pp. 81-89, 2004.

[27] C. Meyer, N. Egosi, and C. Andela, "Concrete with waste glass as aggregate," in Proceedings of the 4th Materials Engineering Conference, vol. 2, pp. 1388-1397, Washington, DC, USA, November 1996.

[28] S. Laldji and A. Tagnit-Hamou, "Glass frit for concrete structures: a new, alternative cementitious material," Canadian Journal of Civil Engineering, vol. 34, no. 7, pp. 793-802, 2007.

[29] V. S. Panchakarla and M. W. Hall, "Glascrete?-disposing of non-recyclable glass," in Proceedings of the 4th ASCE Materials Engineering Conference, pp. 509-518, Washington, DC, USA, November 1996.

[30] C. H. Chen, R. Huang, J. K. Wu, and C. C. Yang, "Waste E-glass particles used in cementitious mixtures," Cement and Concrete Research, vol. 36, no. 3, pp. 449-456, 2006.

[31] M. J. Terro, "Properties of concrete made with recycled crushed glass at elevated temperatures," Building and Environment, vol. 41, no. 5, pp. 633-639, 2006.

[32] BS 3892, Pulverized-fuel ash: part 1. Specification for pulverized-fuel ash for use with Portland cement. British Standard, 1997.

[33] C. S. Poon, X. C. Qiao, and Z. S. Lin, "Pozzolanic properties of reject fly ash in blended cement pastes," Cement and Concrete Research, vol. 33, no. 11, pp. 1857-1865, 2003.

[34] C. S. Poon and D. W. S. Ho, "A feasibility study on the utilization of r-FA in SCC," Cement and Concrete Research, vol. 34, no. 12, pp. 2337-2339, 2004.

[35] BS EN 10016 Part 3: non-alloy steel rods for drawing and/or cold rolling. Specific requirements for rimmed and rimmed substitute low carbon steel rod, 1995.

[36] S. J. Barnett, S. G. Millard, M. N. Soutsos, G. Schleyer, A. Tyas, and T. T. Le, "Ultra high performance fibre reinforced concrete for explosion resistant structures," in Proceedings of the International Conference Entitled Concrete Platform, pp. 565-575, Belfast, UK, 2007.

[37] BS EN 1881 Part 116: testing concrete. Method for determination of compressive strength of concrete cubes, 1983.

[38] BS EN 12390 Part5: testing hardened concrete. Flexural strength of test specimens, 2000.

[39] BS EN 4551 Part1: methods of testing mortars, screeds and plasters, 1998.

[40] P. Richard and M. Cheyrezy, "Reactive powder concretes with high ductility and 200-800 MPa compressive strength," Concrete Technology, vol. 144, pp. 507-525, 1994. 

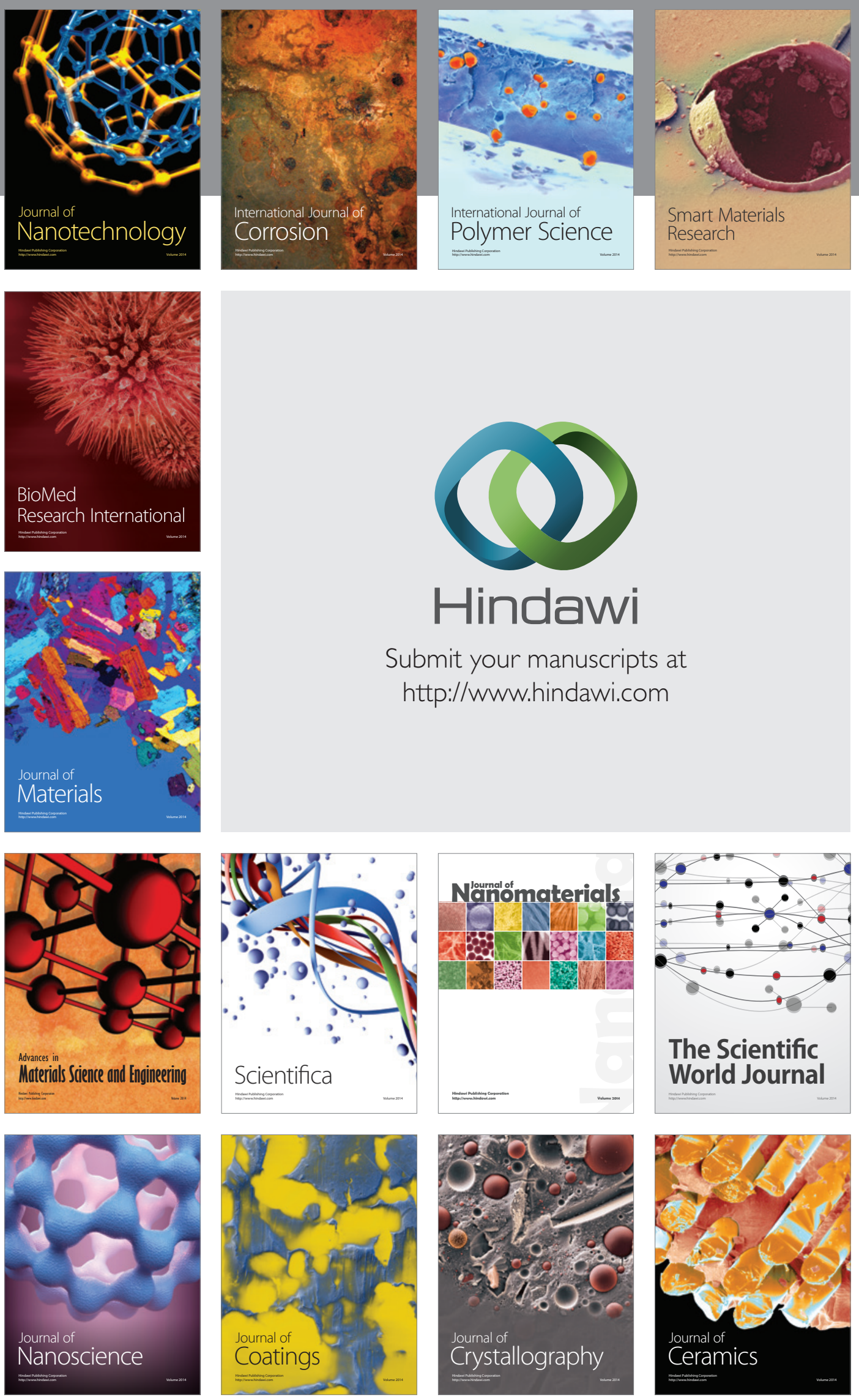

The Scientific World Journal

Submit your manuscripts at

http://www.hindawi.com

\section{World Journal}

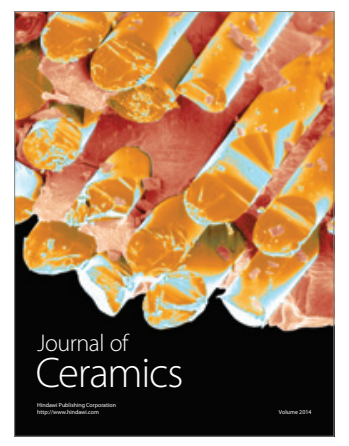

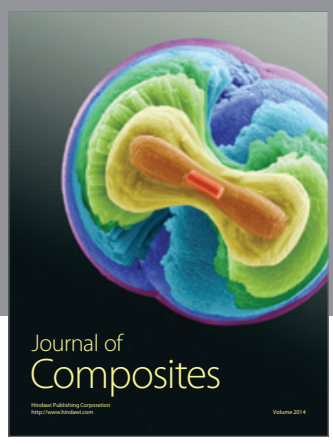
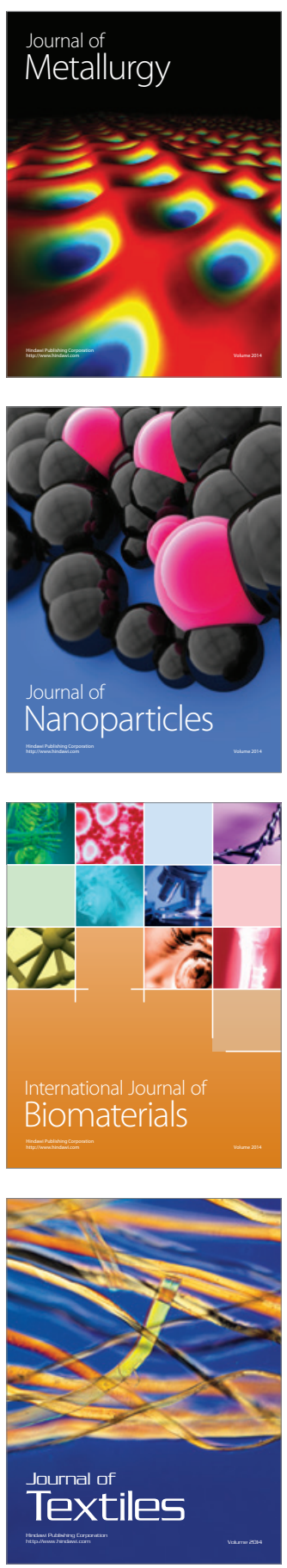